tissue of the bone, and between the layers which form its walls, rending the latter asumder, and expanding them to considerable thickness. Here, too, the cancellous tissue at one part of the femur is solid, very hard, "ivory-like," presenting precisely the appearance described to belong to osteoids. When the disease originates in the cancellous texture of the interior of the bones, it is generally in the articular extremities, rarely in the medullary tubes of their shafts ; and it is remarkable how long the articular cartilages resist the ravages of the disease, and preserve the immunity of the joint long after the adjacent part of the bone has been entirely destroyed.

Soft cancer sometimes attacks the muscles primarily, and now and then it makes its appearance in the skin. When it does so the tissue of the cutis and of the subcutaneous areolar membrane, become infiltrated with the morbid product, and the surface of the skin may be raised into little rounded tumours, somewhat resembling those occurring in molluscum. Hence the term "mollusciform" cancer has been applied to the disease presenting this form.

The difficulties in the diagnosis of soft cancer are practically very many and very great. I can but warn you of them, for experience and caution only can prevent your being occasionally deceived. Probably I am correct in saying that no one other disease has been the source of so many capital blunders in the practice of surgery. In the first place, the age of the patient, his healthy florid complexion, and well-nourished frame, often throw us off our guard, and prevent the suspicion of so desperate a disease. Secondly, the elasticity of the tumour, which the nicest touch may be unable to discriminate from fluctuation, together with its quick formation, the vascularity, tenderness, and perhaps œdema of the superficial tissues, suggest the probability of an abscess; but blood instead of pus follows the incision, and a probe or the finger passes into a soft brain-like mass, small portions of which probably escape, and present the general and microscopical characters of medullary cancer. The same features that cause encephaloid tumour to be mistaken for an abscess, or some of them, are likely to cause it to be mistaken for a cyst or a fatty growth. I have already mentioned an instance of this kind, in which an operation, commenced for the purpose of removing a fatty tumour, was suspended in consequence of the hæmorrhage that ensued, and the discovery that the disease was of malignant nature. Thirdly, these encephaloid tumours, owing to the number and size of the vessels distributed to them, are occasionally found to be attended with pulsation, and have, for that reason, been, in several instances, mistaken for aneurism, and treated by ligature of the neighbouring large vessels. Thus the femoral artery has been taken for a pulsating tumour on the inside of the thigh, the internal iliac for a pulsating tumour of the buttock, and the common iliac for a pulsating tumour of the iliac region; and in each of these cases the disease proved to be malignant, In all, doubtless, the utmost attention was given to ensure a correct diagnosis ; and in each we may unhesi- tatingly believe that the mistake depended upon the complexity of the symptoms rather than upon any want of tact or caution on the part of the surgeons. There are many other sources of fallacy connected with the diagnosis of soft cancer. I have in two instances known amputation performed for malignant disease of the internal condyle of the femur, by surgeons of eminence, under the impression that the affection was only the common synovial disease of the knee-joint.

\section{ON THE PROGRESS}

or

\section{PUBLIC HYGIẼNE AND SANITARY LEGISLATION IN ENGLAND,}

\section{AND THE ADVANTAGES TO BE DERIVED FROM THEIR} FURTHER EXTENSION.*

\section{BY J. I NGHA M I K I N, Ese.,}

Pellow of the Royal College of Surgeons of England, and Lecturer on Anatomy and Physiology in the Leeds School of Medicine, etc.

Read before the Leeds Pbilosophical Society, March, 1851.

WITh regard to the progress of military hygiène I might also say a good deal ; butt here also I must forbear ; and not wishing to be invidious, will only allude to a few names in connexion with this honorable profession-this efficient upholder of our country's glory - this best preserver of peace, and check upon the tyranny of numbers. By congregating men together in armies disease has frequently broken out with great virulerice. But the cause of this has almost always been from some gross inattention or ignorance of the principles of hygiène. Ignorance of the nature of the soil on which an army is encamping - of the products of the country-of the diseases of the climate-the condition and nature of the food, have too often been deplorably extibited in the history of the campaigns of our army. But military hygiène is no longer disregarded by the medical officer or the general in command; and in the last war the army, under that efficient and indefatigable public servant-that honor to our profession, Sir James McGrigor, was a perfect model with respect to attention to preserving the health of the soldier. Choice of quarters-arrangement of uniform-security of, and attention to, the sick and wounded-attention to diet and the general physical condition and comfort of the soldier; nothing of any moment escaped the eagle eye of this experienced surgeon; and his immortal General, Wellington, knew well how to appreciate the services of such a man.

When Sir James McGrigor (vide Lancet's account) $†$ was appointed Director-General of the medical department of the army, he found it imperfect, the same as Sir Wm. Burnett had done the navy; no professional records of the state of health of the army, or its diseases, or their treatment, existing. No records, except those of a fiscal

- Continued from page 514.

+ See Biographical Sketch of Sir James McGrigor, in the Lancet, ane of the series now publishing. 
nature relating to the expenses of the medical department and sick charges, had been made, or even required by the regulations of the service, from medical officers. He immediately set about reforming the entire management of his office. He issued from time to time orders for returns respecting sickness and treatment from the medical officers of all the regiments in the service. $\mathrm{He}$, for the first time, adopted a nomenclature of disease, according to which medical officers had to make their returns ; a point which introduced great uniformity into medical reports. At first these reports were ordered every six months. It required the greatest energy and incessant labour to bring this plan into successful operation, neither were spared by this indefatigable public officer; as soon as he assumed the duties of Director-General he devoted his whole energies and labour to the wellbeing and hygiènic improvement of the service; rising early at five every morning, and constantly working till ten at night, his confidential correspondence being carried on to a great extent by himself. In this way the army medical department, which had been a mere office, became an important department of the public service. As a department it may be said to have been created by Sir James. After some time it was found that an annual report from each regiment was sufficient; and this has been continued with perfect regularity up to the present time. There are, as the results, now at the Army Medical Board Office, in St. James's Place, upwards of 303 returns, well classed, labelled, and encased, containing a mass of invaluable information respecting the health and general condition of troops in this country and abroad. These records must contain a mine of rich stores, having a most extended bearing on medical and sanitary sciences. The army and the State owe the splendid pathological museum, as well as the libraries at Chatham, to the indefatigable exertions of Sir James McGrigor. The elaborate statistical reports of the army and navy of the empire, which Colonel Tullock, Drs. Wilson, Marshall, and others, have published, demonstrate the improved condition of the public services, and will ever be ranked amongst the most valuable documents in the department of statistical medicine. Mr. Jackson's services have also been very great.

It may be added, in justice to others, that Sir James Grant was chief of the medical department of the army in Belgium in 1815. Mr. Gunning was chief medical officer on the field of Waterloo. Mr. Guthrie is one of our best authorities on the effects and treatment of gun-shot wounds; Mr. Franklin was chief of the medical department of the Queen's troops in India during the late war; Dr. French was chief medical officer of the army during the latter part of the war in China; Dr. Hume was the personal attendant of the Duke during the Peninsular war, and performed other important duties ; and, lastly, the present Professor of Military Surgery in the University of Edinburgh, Sir George Ballinghall, deserves great praise, not only for his valuable lectures and services in this department, but for his zeal and anxiety in endeavouring to persuade the Government to establish military professorships in London and Dublin.
Whilst speaking of the progress of hygiènic matters in connection with the State, I may here allude to the investigations and labours of the first early promoters of the Factory Bill ; for undoubtedly the passing of this Act has been of great moment in a sanitary point of view. The protecting of the lives and health of the young had become a matter of necessity, not only from the avarice of masters, but from the cruelty and neglect of parents. The political promoters and agitators for the promotion of factory legislation, though often led astray by their zeal and enthusiasm, deserve the gratitude of their country; and, in the progress of this, to us, (in this part of the country,) exciting question, the aid, co-operation, and testimony of the members of the medical profession tended more than any other influence to compel the interference of the Legislature. In this town many of my brethren took an active and successful part in this, (at that time) fiercely contested question. Speaking of local efforts and exertions in this and other branches of my subject, I must not omit the name of Thackeray, whose treatise and inquiry on the comparative healthiness of different industrial manufacturing occupations and their effects, is well known to medical men, and was duly appreciated by them, as well as the public generally. Mr. Thackeray's industry, zeal, and talent, were sufficiently proved by this work; and I speak not only my own sentiments, and that from personal acquaintance, but that of others as well, when I say that Leeds suffered a great loss in his premature death. He laboured hard and successfully in what was then almost a new department of medical science; and he was an early and successful promoter of public hygiène, then in its infancy. I must also, in bare justice, couple his name with the earliest founders of provincial medical schools, and commend him as a most zealous promoter and teacher of anatomical science; indeed the profession and public of Leeds owe him much, for it was he who first gave a public course of anatomical lectures in this place; and his exertions ultimately gave origin to the more effective organization of the Leeds Medical School, which has now been successfully, but unostentatiously, carried on for twenty years, as the career of many of its pupils shew. And I need not say that the promotion of a sound and extended course of medical education has a very important bearing upon the extension of hygiène; and that efficient medical men are requisite to advise upon, and carry out, sanitary measures; and officers of health should be something more than able policemen or mere inspectors of nuisances. Besides the passing of a Factory Bill, another useful hygiènic regulation was, the rendering it compulsatory for all owners of ships having a crew of, or carrying, fifty persons on board, to appoint a surgeon to take charge of them. The health and condition of the poor emigrants are thus much better attended to; indeed, we now hear of lords and ladies superintending the fitting up and arrangement of emigrant ships. And as for prisoners in gaols-felons and murderers-they can now, from our new system of prison inspection and regulation, get as good medical superintendence, and much 
more regular attendance, than any honest mechanic in the land; and certainly have smarter dwellings, cleaner apartments, and better provisions, than thousands of the deserving poor. But this, by the way, is one of the crotchets and absurdities of the day :-reforming prisoners by keeping them idle in fine castles-improving so zealously the receptacles for crime before attending to the sad condition, both moral and physical, of too many of the poor in all our large towns.

Another Act of Parliament of immense importance, and having an intimate connexion with public hygiène, was the passing of the Bill for registration of births and deaths; also that for the promotion of vaccination, thins giving the public an opportunity of gratuitous vaccination. The reports of the Registrar-General might alone afford ample materials for a series of interesting papers. The able manner in which these reports are written deservedly obtain the most general commendation, both in and out of the profession. The facts they contain and state so concisely are most instructive and useful ; and, in a hygiènic point of view, the Registrar's reports are not to be equalled by any other public doeument.

The classification of diseases, the accuracy of the statistics, the admirable comments and practical deductions are, from their simplicity and correctness, wonderful steps in advance of what such reports would have been even twenty years ago ; and had time permitted, I might have made use of these reports in elucidation of my subject in the most striking manner, and with great advantage to myself and instruction to my andience. Suffice it to say, on the present occasion, the Registrar-General's statistics and facts abundantly prove how attention to the ordinary precautionary means at our disposal for promoting the health of the community conduces to heatth and longevity; and how, on the other hand, a neglect of the laws of hygiène generates fever, and epidemics, and increases mortality. In these reports we find how the poor, the intemperate, and the unclean, are much more exposed to contamination and contract diseases, which the more affluent, cleanly, and temperate escape. They also show to the most sceptical, and prove over and over again the fact, which cannot be too often repeated, that adequate sewerage, along with an abundant supply of water, cleanliness, whitewashing, ventilation, removal of the source of malaria, and nuisances of all kinds, are the best and most efficient measures for promoting the health and comfort of the community. The queston of expense as to carrying ont these measures adequately in all large towns, is quite of secondary importance, as the good results to be derived from them will soon amply repay the outlay, be that what it may. Another recent public act of hygiène, and one deserving of praise, is the Parliamen. tary inquiry into the cause of accidents in mines, and the very able and voluminous reports which have emanated from such inquiry. These contain numerous useful suggestions for the prevention of accidents in minpe, and the result has been the appointment of inppectons; for it has too often happened that many lives are lost in mines from carelessness in the working of them, as well as from causes scarcely capable of entire removal, under the most prudent management and careful superintendence, though modern art and science promise to work wonders even with fire-damp and choke-damp, as the recent successes in Scotland in staying the progress of an extensive subterranean fire abundantly testify.

To proceed, allow me here to state, that in treating this subject, I must be excused adopting any, precise order, with regard to the dates of public measures bearing on this question, or of accurate and precise adjustment as to priority of original and individual claims, researches, and labours, for it is almost impossible to adopt a strictly consecutive arrangement in furnishing you with a comprehensive outline of the progress of public hyigène in England, or of according with strict justice, the merits due to its numerous class of indefatigable and praiseworthy promoters.*. With regard to the writings during the last fifteen to twenty years, that have conduced most, in my mind, to promote and extend hygiène in general, I must name conspicuously those of Dr. Southwood Smith, the author of the well-written work, "The Philosophy of Health, or an Exposition of the Physical and Mental constitution of Man, with a view to the Promotion of Human Longevity and Happiness," and of Dr. Andrew Combe, the author of the deservedly appreciated work (except for his extreme views on phrenology) “The Principles of Physiology applied to the Preservation of Health, and the Improvement of Physical and Mental Cultivation." The name of Mr. Chadwick is connected with all our improvements of a sanitary kind, and he promises to do much more. Dr. Alexander Kilgour's work also, " On Private Hygiène," and "Treatise on the Ordinary Agents of Life,-On Food -Clothing - Climate - Habitations - Exercise, \&c." The American writers, Dr. Caldwell, "On Physical Education ;" and Dr. Dunglison, "On the Influence of Atmosphere and Locality, Change of Air, Corporeal and Intellectual Pursuits, \&c." The useful and practical lectures of the philanthropic Dr. Hodgkin, "On the means of Promoting and Preserving Health," which he delivered at the Mechanic's Institution, in London, and which were published in a cheap form, probably at the suggestion of Lord (then Henry) Brongham, one of the most able advocates, not only for the education, but for the social improvement of the people. I must also name the late Dr. James Johnson's work "On the Economy of Health;" that of Herbert Mayo, "On the Philosphy of Living;" and the standard treatises of Drs. Paris and Pariera, "On Diet," as well as that of Dr. Robertson, and the numerous works on chemistry, especially organic chemistry, such as the well-known important one of Liebig. Dr. Black's Lectures on Hygiène ; $†$ and those given by professors and teachers where this branch of medical science is incorporated

- If whilet allnding prominently to me writers, I overlook the labours of others, I must be excused for the omisainn, as this paper was somewhat hastily prepared, and with no view at the time of meeting the eye of the public.

+ Publinbed in the Provincial Medical and Surgical Jowrnal. 
amongst the other courses of lectures, have all along tended, with the works named, to give an impetus to this study, and are amongst the earliest and best writers upon it that $I$ can call to mind. But in connexion with them, and in a great measure stimulating and encouraging the labours of such men, I must here include and notice the unceasing and emineut services of the British and Foreign Medical Review," when edited by Drs. Forbes and Conolly, as well as since it changed its editorship. The early numbers of this Review, by its series of able articles on hygiène, and the reviews of such works as those $I$ have just enumerated, did more to call the attention of the Government, the public, as well as the profession, than almost any other journal or publication, prioe to the issuing of the Report of the Health of Towns' Commission, and the more recent voluminous Parliamentary Reports on the sanitary condition of the people.

To the original British and Foreign Medical Review, and the British and Foreign Medico-Chirurgical Review, $I^{*}$ am much indebted, for they have been of great use to me in preparing this paper, and my interest in the subject, as I shall have to state directly, is owing to the perusal of its very earliest numbers; and this Review, under its new editorship and title, continues ably to discuss and promote the cause of hygiène. Whilst alluding to the press, and to medical periodicals, it would be an act of injustice to overlook the untiring exertions, zeal, and talent of the Lancet, and its independent Editor; its pages have ever been open to the cause of hygiène, and have long and ably tended to diffuse hygiènic knowledge, and to promote the welfare of the poor, as well as to advocate the just rights and claims of the medical profession. The passing of the "Medical Witnesses Bill" is due to Mr. Wakley, and his very office as Coroner has often led him to investigate matters of hygiene, and those for the protection of the lives, bealth, and comfort of the people. At present the labours of the Lancet are beyond all praise, in the promoting of the "Analytical Sanitary Commission," and publishing its consequent disclosures; these results I shall have, however, to allude to again at the end of this paper, as they are amongst those of the most recent date, and the inquiries are still going on. The pages of the Medical Gazette, the Provincial Medical and Surgical Journal, and the Medical Times, have also ever been open to the discussion and furtherance of this cause, and many valuable lectures and papers on the subject have appeared in them (as at one time it was thought an almost exclusively medical subject,) and continue to do so, especially the reports on the prevalent diseases and meteorological condition of particular towns and districts. The Bdinburgh Review, the Quarterly Review, and others, have aided the cause, and often published most telling articles, either directly or indirectly connected with the sanitary improvement of the masses; for, to the credit of the press be it spoken, this cause is not now exclusively confined to the medical portion of it, but the leading journals of London, especially the Times, (which is ever on the qui vive to see how the wind blows, and has the talent of foresseeing how to steer its course accordingly,) is a mighty alvocate for sanitary reform and extension, as well as a just appreciator of the labours of medical men, and an able defender of their rights and interests. Indeed the best portion of the press, both metropolitan and provincial, now see the propriety of urging on improvements of a hygiènic nature, seeing that it will best promote to the health, cleanliness, and comfort, of all classes. Our own press in Leeds has certainly done its duty, and public attention is now becoming more and more directed to such beneficial and practical questions as the one we are discussing.

It was from reading a capital article in almost the earliest number of the British and Foreign Medical Review, (the second number of it,) that induced me, fourteen years ago, (and probably it might have had the same effect on others,) to add one's mite in the promotion of the cause of hygiène, and in the promulgation of sound hygiènic principles, and to aid in furnishing facts and information to the party most interested-the public at large. The perusal of the paragraph I am about to quote, was the cause of my preparing a somewhat extended course of "Lectures on Public Hygiène," which were first given in the neighbouring town of Halifax, for the benefit of a public institution, and published in the newspapers, and afterwards delivered in Leeds above thirteen years ago. This, I may be allowed to state, without opening myself to the charge of presumption or egotism, in order to show the effect produced on one's mind, and the practical effect of the suggestion herein contained, and certainly it is a satisfaction to feel that one's earliest public efforts were in such a useful direction, and that the subject was taken up before it was even popular, much less fashionable.

In 1836 the British and Foreign Medical Review thus wrote:- "If we could flatter ourselves that our recommendation would be effectual with the numerous physicians and surgeons who may peruse these pages, we would earnestly impress upon them the duty of assisting in this great, humane, and we may truly say, patriotic labour, of instructing the poor how to be healthy, and thus to facilitate their being virtuous, prosperous, and contented. They alone possess the knowledge which would be to them bealth and life. This great service would not be less worthy of them than those more laborious services which they now give in hospitals and dispensaries to many who ought not to require the aid of charity. The truest, noblest, and most effective charity, is that which teaches the poor to depend on themselves, to avoid the causes of disease, and by preserving their health under all ordinary circumstances to secure the means of providing for such visitations as cure cannot avert. From the works already reviewed, any medical man may, with little trouble, derive materials for lectures to the poorer classes of his town's-people, and his local experience will always furnish him with illustrations. The public will be found grateful for such exertions." They add in another part:- "Any reader versed in the history of this country for the last forty years, must be able to 
call to mind more than one occasion in which a knowledge of the laws of hygiène might have prevented great public loss, and such loss would have been much greater, and more frequent, if the intelligence and research of the medical officers of the army and navy had not led to the discovery of many of these laws by observation. There are melancholy cases of disease against which no prudence would have been effectual, but their number is insignificant compared with that of those that spring from ignorance and neglect. By removing this ignorance, the instances of neglect will be made more rare; and nothing is more certain than that, by increasing the general health of mankind, the general amiability and virtue, and thus in every way the general happiness of human beings is increased at the same time."

The works alluded to, and the article from which I have just given the above quotation, were published in 1835 and 1836. Good results gradually became apparent, especially from the labours, perseverance, and talent of Dr. Southwood Smith, Dr. Arnott, Dr. Kay, (now Dr. Kay Shuttleworth,) and I must in justice add, the indefatigable industry, comprehensive mind, and practical tact of Mr. Chadwick, then Secretary and a most active member of the Poor-Law Commission. Without touching upon the debatable topic (foreign, in fact, to this place) of the merits of the whole regulation and policy of Poor-Law Commissioners, all parties will admit that the inquiries, reports, and suggestions of this body have been of great utility, and deservedly merit a conspicuous place in the history of the recent impetus given to public hygiène. In the fourth annual report of the Poor-Law Commissioners, presented in May, 1838 (vide British and Foreign Review for April 1845) from which I now quote, there were two supplementary reports, one by Dr. Arnott and Dr. Kay, on the prevalence of certain physical causes of fever in the metropolis, which might be removed by proper sanitary measures; the other by Dr. Southwood Smith, on the condition of the poor in Bethnal Green and Whitechapel, and exemplified some of the physical canses of sickness and mortality to which the poor are peculiarly exposed. In the fifth annual report of the Commissioners there is a report from Dr. Smith on the prevalence of fever in twenty metropolitan Unions during the year ending March, 1838. In August, 1839, the Poor-Law Commissioners received instructions from the Secretary of State for the Home Department to inquire to what extent the causes of diseases, mentioned in the reports just named, prevailed amongst the labouring classes in England and Wales. They were thus constituted a Board of Health, not for administration, but for inquiry; and, consequently, in November following the whole administrative machinery of the Commissioners throughout England and Wales, was put in motion for the purposes specified. In November, 1840, instructions were issued from the Home Office to the effect that the inquiry should be extended to Scotland. These extensive and useful inquiries, 80 ably conducted, terminated in the presentation to Parliament of three volumes of Reports, two volumes of Local Reports on the sanitary condition of the labouring population of Great Britain, the first volume on England and Wales, the second on Scotland. The General Report, by Mr. Chadwick, is a condensation of these Local Reports, and has been described (see British and Foreign Medical Review) " as constituting the most valuable and complete treatise on certain departments of medical police ever published, either in this or any other country." As you have access to the work it is quite unnecessary for me to analyse it; but it would be an omission indeed not briefly to allude to its contents. Suffice it to say, Mr. Chadwick demonstrated the evils which were the subject of inquiry in a manner so satisfactory as to cause the prosecution of further inquiries, and finally to State legislative interference.

The comparative unhealthiness of the large manufacturing districts as compared with the purely rural districts had been shown before; and the comparative changes of life in different classes of the community had been accurately ascertained and pointed out; but the satisfactory proof and tracing of cause and effect is shown in cases where the neglect of drainage, cleanliness, and supply of water was found to be universally followed by increased mortality, the generation of fever, and spread of cholera. This consequence was now so prominently displayed as to alarm our legislators, as well as convince the public of the necessity of adopting measures to prevent the increase of such mortality. In our town a valuable inquiry and report of the Town Council on these matters was made; and Mr. Baker, now Sub-inspector of Factories for this district, was very active and zealous in this inquiry, and drew up a map, differently shaded, showing how undrained and dirty portions of the town were more unhealthy than any other part. This map is not novel in its plan,* but was not less useful on that account. He was also an able witness before Parliamentary Committees. Many other members of the Council took an active part in this inquiry. Mr. Chadwick, under the head of "Pecuniary burdens created by the neglect of sanitary measures" gives most convincing proofs and figures of the costliness of inattention to public hygiène, and the then apathy of the Legislature on this matter. He also adduces a vast variety of evidence, showing the effects of preventive measures in raising the standard of health and the chances of life. The comparative inability of poor workmen to improve their own condition, and the necessity of external aid for obtaining this improvement is satisfactorily exhibited and demonstrated beyond doubt in this report. The great influence that a kind employer has, not only over the opinions, but the health and general condition of his workpeople, is well shown and proved to be very great. He alludes to the mills of Catrine in Ayrshire, to the effect of comfortable cottages and dwellings, and the modes of building them, to the effects of public walks and gardens on the health and morals of the

- Vide Bulwer'" "Prance; the State of Crime in the different Departments," ac. Illustrated by a shaded map.-I. 
lower classes, to the patriotic gift of the Arboretum at Derby, by Mr. Strutt, on which a walk of two miles is contrived in eleven acres, and one thousand specimens of shrubs and plants are displayed. I may also add, the great improvement in our own mills, and the apportioning of allotment gardens deserve special mention here; the attention of our Marshalls, Gotts, and others, to the well-being of their work-people is universally admitted. The construction and arrangement of Messrs. Marshall's huge mill is considered one of the sights of the age. After all, we are forced to admit that much remains to be done, in the promotion of the sanitary condition of the working classes, and that riches and station have their duties to perform, as well as their influence to exercise. The poor man works for, and adds to, the wealth of the great capitalist, and he is fairly entitled to assistance as well as advice, by the institution of public measures for his special benefit. I allude now in particular to the interference by local and general Acts of Parliament, compelling the adoption of adequate drainage, the building of a better class of cottages, dwellings and lodging houses for the working classes, the establishment of public baths and washhouses, public walks and parks, and the encouragement of healthy manly pastimes and exercises, and along with them, those institutions for mental improvement, now found to work so admirably-Mechanics' Institutionsto which ere long we shall see added free museums, public halls, and cheap reading rooms. All these means will tend to promote the cause of public hygiène. To return for a moment to Mr. Chadwick : in another section of his able report, he discusses at length the state of the then existing laws for the protection of the public health, and shows their inadequacy to the wants of society, and with his usual skill and tact, makes out a case for legislative interference. Mr. C. is quite at home amongst drains and sewers, and dwells strongly upon the plan of rendering the refuse of towns available in a pecuniary point of view, though it was $\mathrm{Mr}$. Smith, of Deanston, who first suggested the propriety of rendering such refuse profitable to the authorities of towns, by its sale for agricultural purposes. Mr. C. also has an essay on Boards of Health and Medical Police, and brings forward a plan of his own, which includes medical inspection not only for the poor, but for streets, houses, sewers, \&c., also the supervision of surgeons under the Poor-Law, of recruits, factory children, prisons, workhouses, lunatic asylums, public schools, manufactories, and workshops of all kinds, as well as the supervision of mortuary registers, coroner's inquests, \&c. The propriety of such general interference is questionable, as public opinion ought to be sufficient to prevent abuse and grievances in large establishments and public institutions, and the aid of the State should be called upon only when independent and voluntary exertions are unequal to the case. Indeed Mr. Chadwick's plans, reports, and legislation are generally overdrawn, so to speak; he thinks public boards _have.only to draw up a code of rules sufficient to meet any exigency, and that the carrying of them into practice will be sure to follow.) [He errs grievously in this respect; his intentions are good, and his suggestive talent is wonderful, but his schemes are often found impracticable. Witness his recent rules defining the duties of the officers of health.* But I must now pass on to another important step in sanitary legislation; I allude to the appointment of a select committee by the House of Commons, to inquire into the evils arising from interments within large towns, and to the issuing of a Royal Commission for an inquiry into the state of large towns and populous districts.

[To be continued.]

\section{CASE OF IDIOPATHIC GANGRENE OF THE FOOT.}

\section{By G. BotTomley, Esa, Croydon.}

Read at the Nineteenth Annirersary Meeting, held at Brighton,August 13,1351.

I was called, in consultation, to see William Mascall, aged 53, of Croydon, Surrey, on January 16th, 1851, a rather short, stoutly-built man, flabby and lymphatic in appearance. Complexion pale; habits have been somewhat irregular; has lived freely; seldom the worse for liquor, "but drinks little and often;" his usual bevorage is porter, either alone or with gin in it; appetite never very good; has been the subject of dyspeptic symptoms more or less for some years. He is a master builder by occupation, and does a fair amount of manual labour himself.

He states that, on the 7 th of December last, he was running down hill at the top of his speed, when he felt a sudden pain in the calf of his right leg, as "though something had given way deep in." It was very severe at the time, and he had difficulty in walking home in consequence. As it persisted for a few days, and confined him to the house, he obtained medical advice, and used fomentations and lotions. There was no swelling or unnatural appearance of any kind. Gradually the pain subsided, although he has felt more or less at the same-spot ever since, and this foot and leg have been so much"colder than the other ever since this occurrence, as to occasion him to wrap it up in flannel at night, of his own accord. He had never noticed any decrease of temperature in it before. For the last three or four days the right foot has been exceedingly painful, rather red, and swollen, and the day before yesterday he first observed that the great toe had a greenish tint, and that there was a small black spot on that side of it which comes into contact with the adjoining toe. The whole toe became redder, and swelled at_night, and the blackness had spread over nearly the whole of it. On the day previous to these appearances taking place, [his medical attendant applied lotions, and four leeches, to relieve the pain.

Present condition.-The whole of the great toe is of a dark livid hue. The instep is redder than natural, the

- This code of rules"was"publishedlin a recert number of the Provixcial Motical and Surgical Journal.-1. 